
3 Research Square
Preprints are preliminary reports that have not undergone peer review.
They should not be considered conclusive, used to inform clinical practice, or referenced by the media as validated information.

\title{
The Effects of Interval Training on Peripheral Brain Derived Neurotrophic Factor (BDNF) In Young Adults: A Systematic Review and Meta-Analysis
}

Patricia García-Suárez

Facultad de Deportes Campus Ensenada, Universidad Autónoma de Baja California

Iván Rentería

Facultad de Deportes Campus Ensenada, Universidad Autónoma de Baja California

Eric Plaisance

Department of Human Studies, University of Alabama at Birmingham

José Moncada-Jiménez

Human Movement Sciences Research Center, University of Costa Rica

Alberto Jiménez-Maldonado ( $\sim$ jimenez.alberto86@uabc.edu.mx )

Facultad de Deportes Campus Ensenada, Universidad Autónoma de Baja California

Research Article

Keywords: BDNF, interval training, LFK

Posted Date: December 17th, 2020

DOI: https://doi.org/10.21203/rs.3.rs-125526/v1

License: (c) (i) This work is licensed under a Creative Commons Attribution 4.0 International License. Read Full License

Version of Record: A version of this preprint was published at Scientific Reports on April 26th, 2021. See the published version at https://doi.org/10.1038/s41598-021-88496-x. 


\section{Abstract}

The aim of the current meta-analysis was to determine the effects of acute and chronic interval training (IT) on peripheral BDNF concentrations in healthy young adults. A literature search was performed using six databases until February 2020. The TESTEX scale was used to assess the quality of studies. Effect sizes (ES) were computed and two-tailed a values $<0.05$ and non-overlapping $95 \%$ confidence intervals ( $95 \%$ Cl) were considered statistically significant. Heterogeneity, inconsistency $\left({ }^{2}\right)$, and small-study effects using the Luis Furuya-Kanamori (LFK) index were examined. Fifteen studies ( $\mathrm{n}=277$ participants, age $=24 \pm 3 \mathrm{yr}$.) were included. The overall effects of IT on circulating BDNF concentrations were moderate and non-significant $(E S=0.64,95 \% \mathrm{Cl}=-0.01,1.30$, heterogeneous $(p<0.001)$, highly inconsistent $(R=90 \%)$, and with major asymmetry (LFK index $=2.85)$. The acute effect of IT on peripheral BDNF levels was large and significant $(E S=1.22,95 \% \mathrm{Cl}=0.08)$, homogenous $(p<0.001)$, with considerable inconsistency $(R=93 \%)$, and major asymmetry $(\mathrm{LFK}$ index $=3.34)$. The chronic effect of IT on circulating BDNF was large and significant ( $E S=0.93,95 \% \mathrm{Cl}=0.40)$, homogenous $(p<0.001)$, with moderate inconsistency $(R=70 \%)$, and minor asymmetry (LFK index $=1.21)$. Acute and chronic IT, elicited a moderate increase in peripheral BDNF concentrations in a healthy young population.

\section{Introduction}

Brain-derived neurotrophic factor (BDNF) was discovered in the early $1980 \mathrm{~s}^{1}$ and belongs to the neurotrophin family of proteins ${ }^{2}$. Early studies in rodents showed an association between BDNF and synaptic plasticity, neuronal growth, neuronal survival, and cognitive processes ${ }^{3-6}$. BDNF binds to a specific tyrosine kinase receptor which induces TrkB tyrosine phosphorylation and activation in its cytoplasmic and kinase domains BDNF-brain-TrkB. The kinase domain recruits and activates specific proteins in the cytoplasm to activate signaling pathways that regulate cognition and synaptic plasticity 7,8 .

Although different cell types synthesize and release BDNF (e.g. adipocytes, skeletal muscle, immune cells, vascular endothelial cells, among others) ${ }^{9-11}$, the hippocampus of the brain is considered the main source of BDNF in mammals ${ }^{12-14}$. Interestingly, reports indicate that this neurotrophin can cross the bloodbrain barrier ${ }^{15}$ and that peripheral circulating BDNF concentrations are associated with brain function ${ }^{16-18}$. In agreement, studies in humans demonstrate that peripheral BDNF concentrations are positively associated with hippocampus size and cognitive performance ${ }^{19,20}$, and inversely associated with mood disorders ${ }^{21-23}$.

Experimental studies, narrative reviews, and meta-analysis have indicated that aerobic exercise (moderate-intensity continuous training-MICT) increases circulating BDNF concentrations and improves brain function ${ }^{24-26}$. Thus, MICT is considered an effective strategy to induce neuroprotection ${ }^{27}$ and to improved brain function. Despite the many benefits of exercise, perceived or real "lack of time" is reported most frequently as the primary that most individuals around developed or developing countries do not exercise regularly 28,29 .

Interval training (IT) modalities can be performed in a fraction of the time as MICT and have been shown to produce similar improvements in peripheral metabolism compared to MICT ${ }^{30-32}$. By its very nature, IT represents a potential solution for individuals that report "lack of time" as a barrier to exercise participation. IT consists of repeated short and long bouts of high-intensity exercise (near maximal, maximal, or supramaximal intensity -maximal heart rate, $\mathrm{VO}_{2}$ max, peak power output, superior to maximal lactate state-state velocity). High-intensity bouts of exercise are interspersed with recovery periods (lightmoderate exercise intensity or passive recovery), with a full-session of IT requiring $\leq 30$ min to be completed ${ }^{33,34}$. Although there is considerable variation and classifications in the literature, high-intensity interval training (HIIT) and sprint interval training (SIT) are the primary forms of IT reported. HIIT is characterized by near maximal bouts of exercise ranging from 2-4 minutes per interval With SIT, bouts are shorter in length ( 30 s), but are maximal or supramaximal ${ }^{35,36}$ (See Table 1). 
Table 1

Studies included in the meta-analysis.

\begin{tabular}{|c|c|c|c|c|c|c|c|c|c|}
\hline Reference & $\begin{array}{l}\text { Sample } \\
\text { size } \\
\text { (male / } \\
\text { female) }\end{array}$ & Fitness & $\begin{array}{l}\text { Age } \\
\text { (yr.) } \\
M \pm \\
S D\end{array}$ & $\begin{array}{l}\text { BDNF } \\
\text { collection }\end{array}$ & $\begin{array}{l}\text { Exercise Characteristics } \\
\text { (duration/frequency/mode) }\end{array}$ & Protocol & $\begin{array}{l}\text { HIIT } \\
\text { Classification } \\
\text { (by Wen et al } \\
\text { 2019) }\end{array}$ & Main findings & $\begin{array}{l}\text { TESTE } \\
\text { Score }\end{array}$ \\
\hline $\begin{array}{l}\text { Cabral- } \\
\text { Santos et } \\
\text { al } 2016\end{array}$ & $\begin{array}{l}10 \\
(10 / 0)\end{array}$ & $\begin{array}{l}\text { Physically } \\
\text { active }\end{array}$ & $\begin{array}{l}25.2 \\
\pm 1.7\end{array}$ & Serum & $\begin{array}{l}\text { Crossover acute high- } \\
\text { intensity exercise/ } \\
\text { motorized treadmill }\end{array}$ & $\begin{array}{l}\text { High }(2.5 \mathrm{~km}) \\
\text { and low } \\
(1.25 \mathrm{~km}) \\
\text { session at } \\
1: 1 \text { min } \mathrm{VO}_{2 \max } \\
\text { velocity with } \\
\text { passive } \\
\text { recovery }\end{array}$ & $\begin{array}{l}\text { Acute } \\
\text { moderate- } \\
\text { volume and } \\
\text { moderate- } \\
\text { interval. }\end{array}$ & $\begin{array}{l}\text { Both protocols } \\
\text { increased BDNF } \\
\text { concentrations. } \\
\text { Nonetheless, the } \\
\text { BDNF response } \\
\text { was not } \\
\text { dependent of } \\
\text { exercise volume }\end{array}$ & 7 \\
\hline $\begin{array}{l}\text { DiBattista } \\
\text { et al } 2018\end{array}$ & $\begin{array}{l}11 \\
(11 / 0)\end{array}$ & $\begin{array}{l}\text { Physically } \\
\text { active }\end{array}$ & $\begin{array}{l}28.8 \\
\pm 5.3\end{array}$ & Plasma & $\begin{array}{l}\text { Acute and after } 2 \text { weeks/ } \\
\text { three times a week/cycle- } \\
\text { ergometer }\end{array}$ & $\begin{array}{l}\text { 3-min warm-up } \\
\text { at } 50 \mathrm{~W}, 8 \times 60 \mathrm{~s} \\
\text { intervals in } \\
\text { sessions } 1-2 \text {, } \\
10 \times 60 \mathrm{~s} \\
\text { intervals in } \\
\text { sessions } 3-4, \\
12 \times 60 \mathrm{~s} \\
\text { intervals in } \\
\text { sessions } 5-6 \text { at } \\
\mathrm{W}_{\text {peak }} \\
\text { interspersed } \\
75 \text { s of active } \\
\text { recovery and } \\
3 \text { min cool- } \\
\text { down at } 50 \mathrm{~W}\end{array}$ & $\begin{array}{l}\text { Short-term, } \\
\text { moderate- } \\
\text { volume and } \\
\text { moderate- } \\
\text { interval HIIT }\end{array}$ & $\begin{array}{l}\text { Both first and } \\
\text { last session } \\
\text { increased BDNF } \\
\text { concentrations } \\
\text { immediately } \\
\text { after the } \\
\text { exercise session, } \\
\text { ST-HIIT did not } \\
\text { change BDNF } \\
\text { levels at } \\
\text { baseline }\end{array}$ & 6 \\
\hline $\begin{array}{l}\text { Figuereido } \\
\text { et al } 2019\end{array}$ & $\begin{array}{l}11 \\
(11 / 0)\end{array}$ & $\begin{array}{l}\text { Physically } \\
\text { active }\end{array}$ & $\begin{array}{l}22.5 \\
\pm 5.4\end{array}$ & Serum & $\begin{array}{l}\text { Acute and eight week } \\
\text { intervention /motorized } \\
\text { treadmill }\end{array}$ & $\begin{array}{l}5 \text {-min warm-up } \\
\text { at } 50 \% \mathrm{VO}_{2 \max } \\
\text { speed, } 60 \mathrm{~s} \\
100 \% \mathrm{sVO}_{2 \max } \\
\text { with } 60 \mathrm{~s} \\
\text { passive } \\
\text { recovery (no } \\
\text { exercise) until } \\
\text { completion of } \\
5 \mathrm{~km} \text {. }\end{array}$ & $\begin{array}{l}\text { Acute, high- } \\
\text { volume, } \\
\text { moderate- } \\
\text { interval HIIE }\end{array}$ & $\begin{array}{l}\text { BDNF levels } \\
\text { increased after } \\
\text { the session } \\
\text { completion } \\
\text { compared at } \\
\text { baseline }\end{array}$ & 5 \\
\hline $\begin{array}{l}\text { Gmiat et } \\
\text { al } 2017\end{array}$ & $\begin{array}{l}14 \\
(0 / 14)\end{array}$ & Sedentary & $\begin{array}{l}30.8 \\
\pm \\
18.6\end{array}$ & Serum & $\begin{array}{l}\text { Acute high intensity } \\
\text { exercise/ whole body } \\
\text { circuit }\end{array}$ & $\begin{array}{l}3 \times 30 \text { s of } \\
\text { AMRAP of } 10 \\
\text { circuit whole } \\
\text { body exercises } \\
\text { (i.e., jumping } \\
\text { jacks, push-ups, } \\
\text { abdominal } \\
\text { crunch, squat, } \\
\text { plank, triceps } \\
\text { dips, high } \\
\text { knees/running, } \\
\text { lunges, push-up } \\
\text { with rotations } \\
\text { and side plank) } \\
\text { with 2-min } \\
\text { recovery } \\
\text { between sets }\end{array}$ & $\begin{array}{l}\text { Acute, high- } \\
\text { volume, } \\
\text { short-interval } \\
\text { HIIE }\end{array}$ & $\begin{array}{l}\text { noted decrease } \\
\text { of BDNF after } \\
1 \mathrm{~h} \mathrm{HIIE} \mathrm{was} \\
\text { present in both } \\
\text { young and } \\
\text { middle age } \\
\text { participants }\end{array}$ & 7 \\
\hline $\begin{array}{l}\text { Heibisz et } \\
\text { al } 2018\end{array}$ & $\begin{array}{l}26 \\
(17 / 9)\end{array}$ & Sportsmen & $\begin{array}{l}19.2 \\
\pm 5.2\end{array}$ & Serum & $\begin{array}{l}6 \text { months/ } 2-3 \text { sessions a } \\
\text { week/ cycle-ergometer }\end{array}$ & $\begin{array}{l}\text { HIIT: } 5 \text { to } 75- \\
\text { min bouts at } \\
85-95 \% \mathrm{P}_{\max } \\
\text { with } 12 \text {-min of } \\
\text { moderate } \\
\text { activity efforts } \\
\text { at } 55-60 \% \mathrm{P}_{\max } \\
2 \mathrm{x} \text { a week } \\
\text { SIT: } 3 \times 3 \text { to } 4 \\
30 \text { s bouts at } \\
\text { all-out effort } \\
\text { with } 90 \text { s of } \\
\text { active recovery } \\
\text { at } 50 \mathrm{~W} \text { and } 25- \\
\text { min of low } \\
\text { effort }(45-55 \% \\
\text { Pmax) between } \\
\text { sets }\end{array}$ & $\begin{array}{l}\text { HIIT: Long- } \\
\text { term, high- } \\
\text { volume, } \\
\text { Long-interval } \\
\text { training } \\
\text { SIT: Long- } \\
\text { term, } \\
\text { moderate- } \\
\text { volume, SIT }\end{array}$ & $\begin{array}{l}\text { Decreases of } \\
\text { BDNF } \\
\text { concentrations } \\
10 \text { and } 60 \mathrm{~min} \\
\text { after sprint test } \\
\text { in the SIT group } \\
\text { after } 2 \text { and } 6 \\
\text { month } \\
\text { intervention }\end{array}$ & 11 \\
\hline
\end{tabular}

Note: AMRAP: As many repetitions as possible, BDNF: Brain-Derived Neurotrophic Factor. CON: Control group, HIIE: High Intensity Intermittent Exercise, HIIT: High Intensity Interval Training, MAP: Maximal aerobic power, $P_{\text {max }}$ : Maximal power, SIT: Sprint Interval Training, ST-HIIT: Short-term High Intensity Interval Training, $\mathrm{VO}_{2 \text { max }}$ : Maximal speed reached during $\mathrm{VO}_{2 \max }, \mathrm{VO}_{2 \text { max }}$ : Maximal oxygen consumption, $\mathrm{VO}_{2 \text { peak }}$ : Peak oxygen consumption, $\mathrm{W}_{\text {max }}$ : Maximal Wattage, WOD: Workout of day, $\mathrm{W}_{\text {peak: }}$ Peak Wattage. 


\begin{tabular}{|c|c|c|c|c|c|c|c|c|c|}
\hline Reference & $\begin{array}{l}\text { Sample } \\
\text { size } \\
\text { (male / } \\
\text { female) }\end{array}$ & Fitness & $\begin{array}{l}\text { Age } \\
(y r .) \\
M \pm \\
S D\end{array}$ & $\begin{array}{l}\text { BDNF } \\
\text { collection }\end{array}$ & $\begin{array}{l}\text { Exercise Characteristics } \\
\text { (duration/frequency/mode) }\end{array}$ & Protocol & $\begin{array}{l}\text { HIIT } \\
\text { Classification } \\
\text { (by Wen et al } \\
\text { 2019) }\end{array}$ & Main findings & $\begin{array}{l}\text { TESTE) } \\
\text { Score }\end{array}$ \\
\hline $\begin{array}{l}\text { Heisz et al } \\
2017\end{array}$ & $\begin{array}{l}66 \\
(24 / 42)\end{array}$ & Sedentary & $\begin{array}{l}20.7 \\
\pm 2.8\end{array}$ & Serum & $\begin{array}{l}6 \text { weeks/ 3 times a week/ } \\
\text { cycle-ergometer }\end{array}$ & $\begin{array}{l}\text { 3-min warm-up } \\
\text { at } 50 \mathrm{~W}, 10 \times \\
60 \text { s of high } \\
\text { intensity bouts } \\
\text { performed at } ~ \\
80 \% \mathrm{~W}_{\text {max }} / \sim 85- \\
95 \% \mathrm{HR}_{\text {peak }} \\
\text { combined with } \\
60 \text { s active } \\
\text { recovery at } \\
30 \% \mathrm{~W}_{\text {max }} \text { and } \\
2-\text { min cool- } \\
\text { down at } 50 \mathrm{~W}\end{array}$ & $\begin{array}{l}\text { Mid-term, } \\
\text { moderate- } \\
\text { volume, } \\
\text { moderate- } \\
\text { interval HIIT }\end{array}$ & $\begin{array}{l}\text { BDNF did not } \\
\text { significantly } \\
\text { change from the } \\
\text { intervention, } \\
\text { however } \\
\text { individual } \\
\text { differences } \\
\text { between low and } \\
\text { high responders } \\
\text { to exercise are } \\
\text { directly related } \\
\text { to the increase } \\
\text { of BDNF } \\
\text { concentrations }\end{array}$ & 11 \\
\hline $\begin{array}{l}\text { Kujach et } \\
\text { al } 2019\end{array}$ & $\begin{array}{l}36 \\
(36 / 0)\end{array}$ & $\begin{array}{l}\text { Physically } \\
\text { active }\end{array}$ & $\begin{array}{l}21.3 \\
\pm 1.3\end{array}$ & Serum & Acute/cycle-ergometer & $\begin{array}{l}5 \text {-min warm-up } \\
\text { at } 1.5 \mathrm{~W} / \mathrm{kg} \\
\text { body mass } \\
\text { followed by } 6 \times \\
30 \mathrm{~s} \text { all-out bout } \\
\text { with fly-wheel at } \\
0.075 \mathrm{kG} / \mathrm{kg} \\
\text { with resting } \\
\text { periods of } 4.5- \\
\text { min }\end{array}$ & $\begin{array}{l}\text { Acute, low- } \\
\text { volume, SIT }\end{array}$ & $\begin{array}{l}\text { Increase of } \\
\text { peripheral BDNF } \\
\text { in experimental } \\
\text { group was } \\
\text { correlated with } \\
\text { the significant } \\
\text { increase in } \\
\text { blood Lactate }\end{array}$ & 11 \\
\hline $\begin{array}{l}\text { Murawska } \\
\text { et al } 2015\end{array}$ & $\begin{array}{l}12 \\
(7 / 5)\end{array}$ & $\begin{array}{l}\text { Physically } \\
\text { active }\end{array}$ & $\begin{array}{l}25.6 \\
\pm 5.8\end{array}$ & Serum & $\begin{array}{l}3 \text { months/ } 2 \text { times a } \\
\text { week/CrossFit, whole body } \\
\text { workout combined with } \\
\text { treadmill or cycling }\end{array}$ & $\begin{array}{l}\text { 60-min of WOD: } \\
\text { 15-min strength } \\
\text { training } \\
\text { (dumbbells and } \\
\text { bars) followed } \\
\text { with 10-min } \\
\text { whole body } \\
\text { aerobic exercise } \\
\text { circuit and } \\
\text { finishing with } \\
\text { 15-min of } \\
\text { cycling or } \\
\text { treadmill }\end{array}$ & $\begin{array}{l}\text { Long-term, } \\
\text { high-volume, } \\
\text { Long-interval } \\
\text { HIIT }\end{array}$ & $\begin{array}{l}\text { Baseline BDNF } \\
\text { increased after } \\
\text { intervention, } \\
\text { then lowered } \\
\text { after progressive } \\
\text { Wingate test in } \\
\text { males but no } \\
\text { changes in } \\
\text { women }\end{array}$ & 11 \\
\hline $\begin{array}{l}\text { Nicolini et } \\
\text { al } 2019\end{array}$ & $\begin{array}{l}18 \\
(18 / 0)\end{array}$ & Sedentary & $\begin{array}{l}23.1 \\
\pm\end{array}$ & Serum & $\begin{array}{l}6 \text { weeks/ } 3 \text { sessions a } \\
\text { week/ cycle-ergometer }\end{array}$ & $\begin{array}{l}3-\text { min warm up } \\
\text { at } 50 \% \mathrm{~W}_{\text {peak }}, 5 \\
\times 60 \text { s high } \\
\text { bouts at } 105- \\
135 \% \mathrm{~W}_{\text {peak }} \\
\text { with } 90 \text { s active } \\
\text { recovery at } 30 \% \\
W_{\text {peak }}\end{array}$ & $\begin{array}{l}\text { Mid-term, } \\
\text { low-volume, } \\
\text { moderate- } \\
\text { interval HIIT }\end{array}$ & $\begin{array}{l}\text { Improvement of } \\
\text { cardiorespiratory } \\
\text { fitness but no } \\
\text { significant } \\
\text { changes in } \\
\text { BDNF } \\
\text { concentrations } \\
\text { after } 18 \\
\text { sessions of HIIT } \\
\text { in sedentary } \\
\text { individuals }\end{array}$ & 8 \\
\hline $\begin{array}{l}\text { Rentería } \\
\text { et al } 2019\end{array}$ & $\begin{array}{l}17 \\
(0 / 17)\end{array}$ & Sedentary & $\begin{array}{l}21.5 \\
\pm 1.6\end{array}$ & Serum & $\begin{array}{l}4 \text { weeks/ } 3 \text { times a } \\
\text { week/cycle-ergometer }\end{array}$ & $\begin{array}{l}15-\text { to } 25-\mathrm{min} \text { of } \\
3 \text { to } 530 \mathrm{~s} \\
\text { bouts of high } \\
\text { intensity at } 80 \% \\
\text { of MAP with } 4- \\
\text { min of active } \\
\text { recovery at } 40 \% \\
\text { MAP }\end{array}$ & $\begin{array}{l}\text { Mid-term, } \\
\text { low-volume, } \\
\text { moderate- } \\
\text { interval }\end{array}$ & $\begin{array}{l}\text { BDNF } \\
\text { concentrations } \\
\text { increased after } \\
\text { intervention and } \\
\text { lowered after } \\
\text { graded-exercise } \\
\text { test post-HIIT }\end{array}$ & 7 \\
\hline $\begin{array}{l}\text { Reycraft } \\
\text { et al } 2019\end{array}$ & $8(8 / 0)$ & $\begin{array}{l}\text { Physically } \\
\text { active }\end{array}$ & $\begin{array}{l}23.1 \\
\pm 3\end{array}$ & Plasma & $\begin{array}{l}\text { Crossover acute } \\
\text { training/self-propelled } \\
\text { treadmill }\end{array}$ & $\begin{array}{l}18-\mathrm{min}, 4 \times 30 \mathrm{~s} \\
\text { bouts of all-out } \\
\text { running } \\
\text { interspersed } \\
\text { with } 4 \text { min of } \\
\text { active recovery }\end{array}$ & $\begin{array}{l}\text { Acute, low- } \\
\text { volume, SIT }\end{array}$ & $\begin{array}{l}\text { BDNF } \\
\text { concentrations } \\
\text { were increased } \\
\text { immediately } \\
\text { post SIT and } \\
\text { recovered } \\
\text { baseline } \\
\text { concentrations } \\
30 \text { and } 90 \text { min } \\
\text { after exercise, no } \\
\text { incremental } \\
\text { changes were } \\
\text { observed in } \\
\text { other modalities }\end{array}$ & 7 \\
\hline
\end{tabular}

Note: AMRAP: As many repetitions as possible, BDNF: Brain-Derived Neurotrophic Factor. CON: Control group, HIIE: High Intensity Intermittent Exercise, HIIT: High Intensity Interval Training, MAP: Maximal aerobic power, $P_{\text {max }}$ : Maximal power, SIT: Sprint Interval Training, ST-HIIT: Short-term High Intensity Interval Training, $\mathrm{VO}_{2 \text { max }}$ : Maximal speed reached during $\mathrm{VO}_{2 \max }, \mathrm{VO}_{2 \text { max }}$ : Maximal oxygen consumption, $\mathrm{VO}_{2 \text { peak }}$ : Peak oxygen consumption, $\mathrm{W}_{\text {max }}$ : Maximal Wattage, WOD: Workout of day, $\mathrm{W}_{\text {peak }}$ : Peak Wattage. 


\begin{tabular}{|c|c|c|c|c|c|c|c|c|c|}
\hline Reference & $\begin{array}{l}\text { Sample } \\
\text { size } \\
\text { (male / } \\
\text { female) }\end{array}$ & Fitness & $\begin{array}{l}\text { Age } \\
\text { (yr.) } \\
M \pm \\
S D\end{array}$ & $\begin{array}{l}\text { BDNF } \\
\text { collection }\end{array}$ & $\begin{array}{l}\text { Exercise Characteristics } \\
\text { (duration/frequency/mode) }\end{array}$ & Protocol & $\begin{array}{l}\text { HIIT } \\
\text { Classification } \\
\text { (by Wen et al } \\
\text { 2019) }\end{array}$ & Main findings & $\begin{array}{l}\text { TESTE } \\
\text { Score }\end{array}$ \\
\hline $\begin{array}{l}\text { Rodríguez } \\
\text { et al } 2018\end{array}$ & $6(6 / 0)$ & $\begin{array}{l}\text { Physically } \\
\text { active }\end{array}$ & $\begin{array}{l}22.6 \\
\pm 0.7\end{array}$ & $\begin{array}{l}\text { Serum } \\
\text { and } \\
\text { Plasma }\end{array}$ & $\begin{array}{l}\text { Acute high intensity } \\
\text { exercise/ motorized } \\
\text { treadmill }\end{array}$ & $\begin{array}{l}5 \text {-min warm-up } \\
\text { at } 50- \\
60 \% \mathrm{VO}_{2 \max } \\
\text { followed by } 4 \\
4 \text { min bouts at } \\
85 \% \mathrm{VO}_{2 \mathrm{max}} \\
\text { combined with } \\
3 \text {-min active } \\
\text { recovery at } \\
40 \% \mathrm{VO}_{2 \max }\end{array}$ & $\begin{array}{l}\text { Acute/ high- } \\
\text { volume, long- } \\
\text { interval HIIT }\end{array}$ & $\begin{array}{l}\text { Significant } \\
\text { BDNF increase } \\
\text { after HIIE but the } \\
\text { changes were } \\
\text { not correlated } \\
\text { with the increase } \\
\text { in lactate }\end{array}$ & 7 \\
\hline $\begin{array}{l}\text { Sadowska } \\
\text { et al } 2019\end{array}$ & $8(8 / 0)$ & $\begin{array}{l}\text { Physically } \\
\text { active }\end{array}$ & $\begin{array}{l}23.1 \\
\pm 1.7\end{array}$ & Serum & $\begin{array}{l}6 \text { weeks/ } 5 \text { days a } \\
\text { week/CrossFit combined } \\
\text { with running track field }\end{array}$ & $\begin{array}{l}\text { 50-min of WOD } \\
\text { composed with } \\
\text { aerobic whole } \\
\text { body circuit, } \\
\text { aerobic training } \\
\text { and } \\
\text { weightlifting of } \\
\text { predetermined } \\
\text { sets or AMRAP }\end{array}$ & $\begin{array}{l}\text { Mid-term, } \\
\text { high-volume, } \\
\text { combination } \\
\text { of repeated } \\
\text { sprint and } \\
\text { SIT }\end{array}$ & $\begin{array}{l}\text { Slight increase } \\
\text { of BDNF levels } \\
\text { after CrossFit } \\
\text { training, but no } \\
\text { changes after } \\
\text { aerobic testing } \\
\text { were performed }\end{array}$ & 7 \\
\hline $\begin{array}{l}\text { Saucedo- } \\
\text { Marquez } \\
\text { et al } 2015\end{array}$ & $\begin{array}{l}21 \\
(21 / 0)\end{array}$ & $\begin{array}{l}\text { Physically } \\
\text { active }\end{array}$ & $28 \pm$ & Serum & $\begin{array}{l}\text { Crossover acute } \\
\text { training/cycle-ergometer }\end{array}$ & $\begin{array}{l}20-\min \text { of } 60 \mathrm{~s} \\
\text { at } 90 \% \mathrm{VO}_{2 \mathrm{max}} \\
\text { with } 60 \mathrm{~s} \text { active } \\
\text { rest period }\end{array}$ & $\begin{array}{l}\text { Acute, } \\
\text { moderate- } \\
\text { volume, } \\
\text { moderate- } \\
\text { interval HIIT }\end{array}$ & $\begin{array}{l}\text { Greater increase } \\
\text { of peripheral } \\
\text { BDNF in HIIT } \\
\text { compared to } \\
\text { CON, with a } \\
\text { higher } \\
\text { magnitude of } \\
\text { change in } \\
\text { contrast to } \\
\text { baseline } \\
\text { measures }\end{array}$ & 11 \\
\hline $\begin{array}{l}\text { Slusher et } \\
\text { al } 2018\end{array}$ & $\begin{array}{l}13 \\
(13 / 0)\end{array}$ & Sedentary & $\begin{array}{l}23.6 \\
\pm 1.0\end{array}$ & $\begin{array}{l}\text { Serum } \\
\text { and } \\
\text { Plasma }\end{array}$ & $\begin{array}{l}\text { Acute high intensity } \\
\text { exercise/ cycle-ergometer }\end{array}$ & $\begin{array}{l}5-\min , 20 \mathrm{~s} \\
170 \% \mathrm{VO}_{2 \text { peak }} \text { at } \\
5.5 \% \\
\text { bodyweight } \\
\text { interspersed } \\
\text { with } 10 \mathrm{~s} \text { active } \\
\text { recovery }\end{array}$ & $\begin{array}{l}\text { Acute, low- } \\
\text { volume, SIT }\end{array}$ & $\begin{array}{l}\text { Serum BDNF } \\
\text { increased } \\
\text { significantly } \\
\text { after HIIE and } \\
\text { remained higher } \\
\text { following the } \\
\text { completion of } \\
\text { executive } \\
\text { function test; } \\
\text { otherwise } \\
\text { plasma BDNF } \\
\text { was not } \\
\text { modified in } \\
\text { either post-HIIE } \\
\text { or after } \\
\text { completion of } \\
\text { executive } \\
\text { function text }\end{array}$ & 7 \\
\hline
\end{tabular}

Note: AMRAP: As many repetitions as possible, BDNF: Brain-Derived Neurotrophic Factor. CON: Control group, HIIE: High Intensity Intermittent Exercise, HIIT: High Intensity Interval Training, MAP: Maximal aerobic power, $P_{\text {max }}$ : Maximal power, SIT: Sprint Interval Training, ST-HIIT: Short-term High Intensity Interval Training, $\mathrm{VO}_{2 \max }$ : Maximal speed reached during $\mathrm{VO}_{2 \max }, \mathrm{VO}_{2 \max }$ : Maximal oxygen consumption, $\mathrm{VO}_{2 \text { peak }}$ : Peak oxygen consumption, $\mathrm{W}_{\text {max }}$ : Maximal Wattage, WOD: Workout of day, $\mathrm{W}_{\text {peak }}$ : Peak Wattage.

Therefore, the purpose of this systematic review and meta-analysis was to examine the effects of acute and chronic IT on circulating BDNF concentrations in apparently healthy young adults. In regard that the exercise response of BDNF is influenced by gender ${ }^{37,38}$, fitness level ${ }^{39,40}$, and exercise intensity $41-43$ an analysis of moderator variables by subgroups were performed. Finally, we assess the differences of changes in circulating BDNF between serum and plasma after IT.

\section{Methods}

\section{Overview}

This study followed the methodologies to complete a systematic review and meta-analysis suggested by Moher et al. (2015) ${ }^{44}$ and the International Prospective Register of Systematic Reviews (PROSPERO). The protocol was registered at PROSPERO under the code (disclosed following peer-review).

Eligibility criteria

Studies that met the following criteria were included: 1) randomized controlled trials (RCT) and controlled trials without randomization (pre-test), 2) healthy normal-weight participants (as determined by a body mass index (BMI) between 20 to $24 \mathrm{~kg} / \mathrm{m}^{2}$ or a body fat mass $<20 \%$ for men and $<28 \%$ for women, 3 ) young adults (18 to 40 year. old), 4) male and female of different ethnic groups, 5) interventional studies, 6) serum and plasma circulating BDNF, 7) studies including participants free of any pharmacological prescription medication or drug, or recreational smoking, 8) studies using the enzyme-linked

Page 5/16 
immunosorbent assay (ELISA) method to determine circulating BDNF. Studies that met the following criteria were excluded: 1) studies involving overweight and obese participants (BMl $\left.>25 \mathrm{~kg} / \mathrm{m}^{2}\right), 2$ ) children and adolescents (<18 years old), 3) middle age and elderly people ( $>40$ year. old), 4) pregnant women, and 5) cross-sectional studies.

\section{Information sources}

Seven electronic databases (PubMed, Science Direct Collection, Scopus, SpringerLink, Taylor \& Francis journals, Wiley Online Library, Web of Science) were searched for potentially eligible studies in English. In addition, cross-referencing from retrieved studies was conducted. The last searches were conducted on February 2020 by two researches (PCG-S and AJ-M).

\section{Search strategy}

Search strategies were developed using text words as well as Medical Subject Headings associated with the effects of exercise on BDNF. The search strategy included the following key words in English language: The search strategy included the following key words in English language: interval training, BDNF, intermittent training, high intensity intermittent training, interval running, brain-derived neurotrophic factor, high-intensity interval training, HIIT, sprint interval training, SIT, CrossFit ${ }^{\circledR}$, Tabata ${ }^{\circledR}$. Boolean operators AND, OR, NOT OR Mesh option were used to concatenate the search terms (key words). A secondary search was performed by screening the reference list of the selected studies and relevant review articles. Finally, a forward citation tracking of the selected studies was conducted through Scopus. An example of the search strategy for one of the databases searched (PubMed) is shown in supplementary Fig S1 online.

\section{Study records and selection}

All studies to potentially be screened were imported into Mendeley software, version 1.19.3 (Elsevier Inc., New York, NY, USA). One author then removed duplicates both electronically and manually. A copy of the database was then provided to two authors for duplicate screening. The two authors selected all studies, independent of each other. The full report for each article was obtained for all titles and abstracts that appeared to meet the inclusion criteria or where there was any uncertainty. Reasons for exclusion were coded as one or more of the following: 1) duplicates 2) missing or incomplete descriptive statistics 3) inappropriate research design 4) language different to English 5) abstracts only and 6) animal model. Upon completion, the two authors met and reviewed their selections. Given the small number of studies selected, discrepancies were reached by consensus. Based on the final number of studies to be included, the overall precision of the searches was calculated by dividing the number of studies included by the total number of studies screened after removing duplicates. The number needed to read (NNR) was then calculated as the inverse of the precision ${ }^{45}$.

\section{Data extraction}

Titles and/or abstracts of studies retrieved using the search strategy and those from additional sources were screened independently by two review authors (PCGS and AJM) to identify studies that potentially met the inclusion criteria outlined above. The full text of these potentially eligible studies was retrieved and independently assessed for eligibility by two review team members. Any disagreement between them over the eligibility of particular studies was resolved through discussion with a third reviewer (IR).

The studies were retrieved in Mendeley software, version 1.19.3 (Elsevier Inc., New York, NY, USA) and exclusion reasons were recorded. Data were exported to a standardized, pre-piloted Excel spreadsheet used to extract data from the included studies for assessment of study quality and evidence synthesis. The extracted information included publication year, participant demographics and baseline characteristics (e.g., gender, age, cardiorespiratory fitness level), details of the intervention (e.g., exercise frequency, intensity, duration, session duration, total duration of the intervention, dropouts) and control conditions, outcomes (i.e., serum and plasma BDNF) (mean and standard deviation). Two review authors extracted data independently and discrepancies were identified and resolved through discussion with a third author. Missing data were requested from study authors.

\section{Primary outcome}

The primary outcome was the change in peripheral BDNF concentration between control and experimental conditions (i.e., repeated measures designs) or groups (i.e., independent group designs). It is worth noting the first post-exercise BDNF measure was considered.

\section{Risk of bias assessment in individual studies}

Two review authors independently assessed the risk of bias in included studies by using the Tool for the Assessment of Study Quality and Reporting in Exercise (TESTEX) ${ }^{46}$. The TESTEX is a 12-item ( 5 points for study quality and 7 points for reporting) and 15 -point scale (5 points for study quality and 10 points for reporting) developed to facilitate a comprehensive review of exercise training trials. Disagreements between the review authors over the risk of bias in particular studies were resolved by discussion, with involvement of a third review author where necessary.

\section{Data synthesis and calculation of effect sizes}

The effect size (ES) was calculated as the difference between means according to the methodology proposed by Borenstein, Hedges, Higgins, and Rothstein (2009) ${ }^{47}$. For the calculation, the initial score (pre-test) of BDNF was compared with the final score (post-test) after an intervention (exercise). The ES was subsequently adjusted to take into account the bias introduced by small samples ${ }^{48}$. For the analysis, the random effects model was used, which assumes that ESs vary between studies ${ }^{47,49}$. In this study, ES was interpreted as trivial ( 0 to 0.19$)$, small $(0.20$ to 0.49$)$, moderate $(0.50$ to 0.79$)$ and large ( $\left.\geq 0.80\right)$. ANOVA and independent samples t-test were used to determine mean ES differences between categorical moderator variables.

\section{Meta-biases}


Small-study effects (publication bias, etc.) were assessed following current recommendations ${ }^{51,52}$. The degree of heterogeneity of the studies was analyzed through Cochran's Q test ${ }^{53}$ and the degree of consistency between the studies was calculated through the $P^{2}$ test ${ }^{54}$. The $P^{R}$ statistic ranges from 0 to $100 \%$, and is interpreted as low ( $\leq 25 \%)$, moderate $(26-74 \%)$ and high $(\geq 75 \%){ }^{54}$. The effect of the studies with small samples was determined by the Doi plot and LFK index ${ }^{51}$. LFK index values outside the interval between -1 and +1 are considered consistent with asymmetry (i.e. publication bias) ${ }^{55}$. An a level $\leq 0.05 \%$ and $95 \%$ confidence intervals $(95 \% \mathrm{Cl})$ that did not include zero $(0)$ were considered to represent statistically significant small-study effects.

\section{Software used for data synthesis}

All data were analyzed using IBM SPSS Statistics for Windows, Version 23.0 (Armonk, NY), Microsoft Excel V.2010 and the Meta XL V.5.3, 2016 add-in software for Excel (EpiGear Intl., Queensland, Australia).

\section{Results}

\section{Study characteristics}

A flow diagram that depicts the search process for study selection is shown in Fig. 1. After initially identifying 4378 citations and removing 3620 duplicates both electronically and manually, 758 citations were screened. Of these, 18 studies met the criteria for inclusion, and three studies were excluded (one study used a sample with metabolic syndrome, one study used a cross-sectional design, and one study used a different exercise intervention). The major reasons for exclusion were: 1 ) duplicates (82.7\%), 2) title and abstract did not meet the test subjects' inclusion criteria (16.9\%), 3) Cross-sectional study and other modalities different from IT (0.7\%). The precision of the search, excluding duplicates, was $2 \%$ while the NNR was 51 . Twenty-two ESs were computed from 15 studies representing 277 participants meeting the criteria for inclusion (Table 1).

\section{Participant and exercise characteristics}

The mean age of the participants was $24 \pm 3$ year., and the mean number of participants in the studies was $19 \pm 15$ participants, with most studies recruiting males (67\%), mixed samples (20\%), and a small number of studies recruiting females (13\%). Participants in the studies were physically active (60\%), sedentary (33\%), and athletes (7\%). Nine studies (60\%) recorded acute exercise responses and six studies (40\%) recorded chronic training effects. Specific types of activities included IT on a cycle-ergometer (54\%), treadmill (27\%), and combined (20\%), including whole-body circuits, CrossFit ${ }^{8}$, and running on a track field (Table 1). Overall, five studies assessed BDNF response on HIIT (34\%) and ten studies in SIT (66\%).

\section{Risk of bias assessment}

Results for risk of bias assessment using the TESTEX scale showed that overall, studies achieved $54.7 \%$ of the quality requirements. Therefore, $45.3 \%$ of the studies were at an unclear or high risk of bias concerning: 1) eligibility criteria specified (100\%), 2) randomization specified (53\%), 3) allocation concealment $(53 \%), 4)$ groups similar at baseline $(53 \%), 5)$ blinding of assessor $(0 \%), 6)$ outcome measures assessed in $85 \%$ of patients (13\%), 7$)$ intention-to-treat analysis (73\%), 8) between-groups statistical comparisons reported (50\%), 9) point measures and measures of variability for all reported outcome measures (80\%), 10) activity monitoring in control groups $(73 \%), 11$ ) relative exercise intensity remained constant $(10 \%)$, and 12 ) exercise volume and energy expenditure (93\%). Given the inability to truly blind participants in exercise intervention trials, all studies (100\%) were considered to be at a high risk of bias for the categories "allocation concealment" and "blinding of assessor". In addition, $87 \%$ of the studies did not report adverse effects and $13 \%$ of the studies reported adherence to exercise interventions.

\section{Data synthesis}

The overall effect of IT on peripheral circulating BDNF concentrations was moderate and non-significant $(\mathrm{ES}=0.64,95 \% \mathrm{Cl}=-0.01,1.30, \mathrm{Fig} .2)$. The studies provided heterogeneous results $(Q=215.66, p<0.001)$, showed high inconsistency $(R=90 \%)$, and major asymmetry (LFK index $=2.85$, see Supplementary Fig S2 online). Two influential studies were detected ${ }^{56,57}$ that changed the overall effect size magnitude $(\mathrm{ES}=0.59)$, statistical significance $(95 \% \mathrm{Cl}=0.09,1.10)$, and minor asymmetry (LFK index $=1.71)$, with no change in consistency $(R=85 \%)$.

The acute effect of IT on circulating BDNF was large and significant ( $E S=1.22,95 \% \mathrm{Cl}=0.08,2.36$, Fig. 3). However, similar to the overall effect, the studies provided heterogeneous results $(Q=165.90, p<0.001)$, and showed high inconsistency $(R=93 \%)$, and major asymmetry (LFK index $=3.34$, see Supplementary Fig. S3 online). The chronic effect of IT on BDNF was large and significant (ES $=0.93,95 \% \mathrm{Cl}=0.40,1.46$, Fig. 4). The studies provided heterogeneous results $(Q=27.04, p<0.001)$, showed moderate inconsistency $(R=70 \%)$, and minor asymmetry (LFK index $=1.21$, see Supplementary Fig. S4 online).

Categorical moderator variable analysis on acute and chronic exercise interventions showed that there is no statistically significant subgroup effect for fitness level, type of training, and medium (blood vs. plasma) for acute and chronic IT (Table 2). There was a strong tendency $(p=0.052)$ for gender in chronic IT analysis; a higher ES was observed in females during chronic IT intervention compared with males (Table 2). For continuous moderators, no significant correlations were found between ES and age for acute $(r=-0.01, p=0.492)$ and chronic $(r=-0.09, p=0.805)$ exercise. No significant correlations were found between ES and sample size for acute $(r=-0.21, p=0.486)$ and chronic $(r=-0.45, p=0.192)$ exercise. 
Table 2

Moderator variables for the effect of acute and chronic exercise on BDNF.

\begin{tabular}{|c|c|c|c|c|c|}
\hline \multirow[t]{2}{*}{ Variable } & \multirow[t]{2}{*}{$\mathrm{n}=$ studies } & \multirow[t]{2}{*}{$\mathrm{ES} \pm \mathrm{SD}$} & \multicolumn{2}{|l|}{$95 \% \mathrm{Cl}$} & \multirow[t]{2}{*}{$p=$} \\
\hline & & & Lower-limit & Upper-limit & \\
\hline \multicolumn{6}{|l|}{ Acute exercise } \\
\hline Gender & & & & & 0.379 \\
\hline Male & 11 & $4.26 \pm 5.76$ & 0.39 & 8.13 & \\
\hline Female & 2 & $0.39 \pm 0.24$ & -1.77 & 2.55 & \\
\hline \multicolumn{6}{|l|}{ Fitness } \\
\hline Sedentary & 3 & $5.49 \pm 8.84$ & -16.47 & 27.46 & 0.532 \\
\hline Active & 10 & $3.12 \pm 4.57$ & -0.15 & 6.39 & \\
\hline Type of training & & & & & 0.934 \\
\hline HIIT & 7 & $3.54 \pm 5.89$ & -1.90 & 8.99 & \\
\hline SIT & 6 & $3.81 \pm 5.46$ & -1.92 & 9.54 & \\
\hline Blood analysis & & & & & 0.483 \\
\hline Plasma & 3 & $5.71 \pm 8.00$ & -14.04 & 25.46 & \\
\hline Serum & 10 & $3.05 \pm 4.88$ & -0.44 & 6.55 & \\
\hline \multicolumn{6}{|l|}{ Chronic exercise } \\
\hline \multicolumn{6}{|l|}{ Gender } \\
\hline Male & 5 & $0.15 \pm 0.40$ & -0.35 & 0.65 & 0.052 \\
\hline Female & 2 & $1.25 \pm 0.06$ & 0.67 & 1.82 & \\
\hline Mixed & 3 & $0.26 \pm 0.60$ & -1.22 & 1.74 & \\
\hline Fitness & & & & & 0.950 \\
\hline Sedentary & 3 & $0.34 \pm 0.77$ & -1.58 & 2.25 & \\
\hline Active & 5 & $0.39 \pm 0.64$ & -0.41 & 1.19 & \\
\hline Athlete & 2 & $0.53 \pm 0.52$ & -4.17 & 5.23 & \\
\hline Type of training & & & & & 0.208 \\
\hline HIIT & 4 & $0.48 \pm 0.69$ & -0.62 & 1.57 & \\
\hline SIT & 3 & $-0.08 \pm 0.29$ & -0.80 & 0.64 & \\
\hline CrossFit ${ }^{\circledR}$ & 3 & $0.78 \pm 0.46$ & -0.36 & 1.92 & \\
\hline
\end{tabular}

\section{Discussion}

The present study was designed to systematically-review and meta-analyze the effects of acute and chronic IT on circulating BDNF concentration in young adults. Overall, acute and chronic IT increased peripheral BDNF concentration. In chronic IT, females showed greater increases in BDNF compared with males. Finally, the study showed that the fitness levels did not regulate the BDNF response after IT, at least in the studied population (apparently healthy young adults).

The data of the current study are in agreement with the previous report focused on the impact of aerobic exercise on peripheral BDNF ${ }^{58}$. In Dinoff's study, the exercise protocols were longer than the interventions analyzed in the current meta-analysis ( $\leq 30 \mathrm{~min} / \mathrm{session}$ ). This finding suggests that IT is an effective treatment to improve brain health with more time efficiency than MICT. The latter condition is concordant with peripheral adaptations induced by IT (e.g., oxidative capacity in muscle, cardiometabolic markers) $30,33,59$.

IT is characterized by lactate accumulation in blood ${ }^{41,60}$. Studies in rodents have demonstrated that blood lactate produced during exercise reaches the brain and enhances expression of genes associated with cognition (i.e. Bdnf) ${ }^{61,62}$. Although in humans this response has not been completely demonstrated, authors suggested a similar effect of blood lactate in brain ${ }^{41,63-65}$. Unfortunately, in the current meta-analysis, there were not enough studies that reported blood lactate changes; consequently it was not possible to develop a meta-regression test to identify the role of this metabolite in the BDNF response.

Non-statistical differences were found among BDNF changes in plasma and serum (Table 2). While some studies did not find statistical differences between BDNF changes in serum and plasma following physical exercise ${ }^{26}$, others reported significant changes in circulating BDNF in plasma compared with serum 58. In previous studies, aerobic, strength, and concurrent training were analyzed; whereas, in the current meta-analysis, IT interventions were examined. 
Circulating BDNF changes are sensitive to training modality ${ }^{41,66}$; therefore, it was not possible to compare our data with other systematic and meta-analytic works ${ }^{26,58}$.

In serum, BDNF concentration is $>50$ fold higher than plasma ${ }^{18,67,68}$. In the periphery, platelets store BDNF; therefore, these cells are considered the major reservoir of circulating BDNF ${ }^{68,69}$. Once activated, platelets release BDNF ${ }^{18,68}$. This process is considered the main mechanism to explain differences between serum and plasma concentrations ${ }^{70,71}$. The evidence suggests that chronic training improves the capacity of platelets to release BDNF ${ }^{18,72}$. Concerning this, we did not discard that the length of interventions examined in the current study was insufficient to modify the platelet's capacity in the BDNF secretion; thus, further studies are necessary to elucidate this hypothesis. In addition, it is known that IT is an exercise modality that increases muscle damage

${ }^{73}$. We believe that this condition could be present in the participants and consequently will generate platelet activation ${ }^{68}$, releasing BDNF to repair muscle injuries ${ }^{74}$. This physiological response might explain the lack of differences among the BDNF changes in serum and plasma (Table 2). Finally, we did not discard that the small numbers of studies included in the current meta-analyses can explain the lack of differences among the blood mediums. Furthermore, plasma studies were fewer than serum studies; this unequal distribution can be a confounding variable to find statistical differences.

Similarly, to the medium, fitness level did not significantly affect the BDNF response to IT. These findings are contrary to previous reports $18,40,58,72,75$. Despite the established negative relationship between fitness level and BDNF response during exhaustive or aerobic exercise ${ }^{40,58}$, biochemical and physiological mechanisms are not fully understood. One hypothesis suggests that well-trained participants have higher BDNF receptor levels in peripheral organs (e.g., skeletal muscle) which could attenuate circulating BDNF changes during exercise ${ }^{76}$. Once it activates the peripheral TrkB receptor, BDNF participates in the repair of skeletal muscle ${ }^{74}$. As indicated above, IT induces muscle damage in well-trained and untrained people ${ }^{73}$; therefore, we did not discard that the lower peripheral BDNF levels were induced by muscular damage after IT. That condition could explain partially the lack of significant differences in BDNF changes between athletes and untrained participants (Table 2). Additionally, perceived stress levels during IT could be other variables to hinder differences among BDNF responses in athletes and untrained people (Table 2). Specifically, IT is perceived as difficult and vigorous in well-trained and untrained population $41,56,73,77,78$. In agreement with this, IT increases systemic cortisol concentrations in athletes and untrained participants ${ }^{43,79-81}$. Cortisol is a hormone that decreases BDNF synthesis ${ }^{82}$. Therefore, higher cortisol levels could be present in the participant (sedentary, active, and athlete participants) after IT, reducing differences in BDNF changes (Table 2). Finally, we do not exclude the possibility that the small numbers of studies included in the current meta-analyses can explain the lack of differences among fitness levels.

We found a high ES (strong tendency) for females compared with males; a difference shown principally in chronic IT (Table 2). This may be explained by the role of steroid hormones since it is known the positive effect of $17 \beta$ estradiol on BDNF synthesis in the brain ${ }^{83-87}$. The estrogen hormone concentrations change during the menstrual cycle ${ }^{88}$; particularly, high levels of estrogen are found during the late follicular phase ${ }^{89}$. In the studies analyzed in the current meta-analysis, the menstrual cycle was not coded; therefore, we do not discard the possibility that some of the blood collection made in females was performed during the follicular phase, resulting in an enhancement effect of estrogen to IT impact on BDNF changes compared to males.

The data of the current meta-analysis are in agreement with prior meta-analysis focused on assessing the impact of physical exercise (e.g., aerobic and strength exercise) on circulating BDNF in young adult and healthy population ${ }^{26,58,90}$. The novelty of the current study is the efficiency of IT to increase peripheral BDNF concentrations, a biomarker of a healthy brain. This finding adds relevant information to previous studies reporting a positive impact of IT on fitness levels ${ }^{91-93}$, and hemodynamic variables ${ }^{94}$. Therefore, the state of the art, based on quantitative analysis suggests that IT may be considered an adequate physical exercise modality to strengthen the health (brain and peripheral physiological functions) in an apparently healthy young adult population.

\section{Declarations}

\section{Acknowledgements.}

The authors are deeply thankful to Fabio Santos-Lira, Eugenia Murawska-Cialowicz, Aaron L. Slusher, Chun-Jung Huang and Alex Di Battista by providing raw BDNF data for the completion of this meta-analysis.

\section{Authors' contributions}

AJ-M conceived the review focus. AJ-M and PCGS reviewed the literature, and analyzed the data. IR and JMJ contributed with the data analysis and interpretation, EPP contributed to the critical revision of the manuscript. AJM drafted the manuscript. PCGS and EPP finalized the manuscript. All authors approved the final version of the manuscript.

\section{Additional Information}

\section{Competing Interest}

The authors declare that they have no conflicts of interest relevant to the content of this review.

Availability of data and material: The data that support the findings of this study are available from the corresponding author on request.

\section{References}

1. Barde, Y. A., Edgar, D. \& Thoenen, H. Purification of a new neurotrophic factor from mammalian brain. EMBO J. 1, $549-553$ (1982).

2. Binder, D. K. \& Scharfman, H. E. Brain derived neurotrophic factor. Growth Factors 22, 123-131 (2004).

Page 9/16 
3. Hall, J., Thomas, K. L. \& Everitt, B. J. Rapid and selective induction of BDNF expression in the hippocampus during contextual learning. Nat. Neurosci. 3, 533-535 (2000).

4. Kang, H. J. \& Schuman, E. M. Neurotrophin-induced modulation of synaptic transmission in the adult hippocampus. J. Physiol. - Paris 89, 11-22 (1995).

5. Korte, M. et al. Hippocampal long-term potentiation is impaired in mice lacking brain-derived neurotrophic factor. Proc. Natl. Acad. Sci. U. S. A. 92, 88568860 (1995).

6. Acheson, A. et al. A BDNF autocrine loop in adult sensory neurons prevents cell death. Lett. to Nat. 374, (1995).

7. Blum, R. \& Konnerth, A. Neurotrophin-mediated rapid signaling in the central nervous system: Mechanisms and functions. Physiology 20, 70-78 (2005).

8. Finkbeiner, S. et al. CREB: A major mediator of neuronal neurotrophin responses. Neuron 19, 1031-1047 (1997).

9. Matthews, V. B. et al. Brain-derived neurotrophic factor is produced by skeletal muscle cells in response to contraction and enhances fat oxidation via activation of AMP-activated protein kinase. Diabetologia 52, 1409-1418 (2009).

10. Chaldakov, G. N., Tonchev, A. B. \& Aloe, L. NGF and BDNF: from nerves to adipose tissue, from neurokines to metabokines. Riv. Psichiatr. $44,79-87$ (2009).

11. Nakahashi, T. et al. Vascular endothelial cells synthesize and secrete brain-derived neurotrophic factor. FEBS Lett. 470, 113-117 (2000).

12. Rasmussen, P. et al. Evidence for a release of brain-derived neurotrophic factor from the brain during exercise. Exp. Physiol. 94, 1062-1069 (2009).

13. Conner, J. M., Lauterborn, J. C., Yan, Q., Gall, C. M. \& Varon, S. Distribution of Brain-Derived Neurotrophic Factor (BDNF) Protein and mRNA in the Normal Adult Rat CNS: Evidence for Anterograde Axonal Transport. (1997).

14. Hofer, M., Pagliusi, S. R., Hohn, A., Leibrock, J. \& Barde, Y. A. Regional distribution of brain-derived neurotrophic factor mRNA in the adult mouse brain. EMBO J. 9, 2459-2464 (1990).

15. Pan, W., Banks, W. A., Fasold, M. B., Bluth, J. \& Kastin, A. J. Transport of brain-derived neurotrophic factor across the blood-brain barrier. Neuropharmacology 37, 1553-1561 (1998).

16. Tang, S. W., Chu, E., Hui, T., Helmeste, D. \& Law, C. Influence of exercise on serum brain-derived neurotrophic factor concentrations in healthy human subjects. Neurosci. Lett. 431, 62-65 (2008).

17. Suliman, S., Hemmings, S. M. \& Seedat, S. Brain-Derived Neurotrophic Factor (BDNF) protein levels in anxiety disorders: Systematic review and metaregression analysis. Front. Integr. Neurosci. 7, 1-11 (2013).

18. Gejl, A. K. et al. Associations between serum and plasma brain-derived neurotrophic factor and influence of storage time and centrifugation strategy. Sci. Rep. 9, 1-9 (2019).

19. Erickson, K. I. et al. Exercise training increases size of hippocampus and improves memory. Proc. Natl. Acad. Sci. 108, 3017-3022 (2011).

20. Inoue, D. S. et al. Acute increases in brain-derived neurotrophic factor following high or moderate-intensity exercise is accompanied with better cognition performance in obese adults. Sci. Rep. 10, 1-8 (2020).

21. Karege, F. et al. Decreased serum brain-derived neurotrophic factor levels in major depressed patients. Psychiatry Res. 109, 143-148 (2002).

22. Kauer-Sant'Anna, M. et al. Traumatic life events in bipolar disorder: Impact on BDNF levels and psychopathology. Bipolar Disord. Suppl. 9, 128-135 (2007).

23. Molendijk, M. L. et al. Serum levels of brain-derived neurotrophic factor in major depressive disorder: State-trait issues, clinical features and pharmacological treatment. Mol. Psychiatry 16, 1088-1095 (2011).

24. Zoladz, J. A. et al. Endurance Training Increases Plasma Brain-Derived Neurotrophic Factor Concentration in Young Healthy Men. J. Physiol. Pharmacol. 59, 119-132 (2008).

25. Huang, T., Larsen, K. T., Ried-Larsen, M., Møller, N. C. \& Andersen, L. B. The effects of physical activity and exercise on brain-derived neurotrophic factor in healthy humans: A review. Scand. J. Med. Sci. Sport. 24, 1-10 (2014).

26. Dinoff, A., Herrmann, N., Swardfager, W., one, C. L.-P. \& 2016, undefined. The effect of exercise training on resting concentrations of peripheral brainderived neurotrophic factor (BDNF): a meta-analysis. ncbi.nlm.nih.gov.

27. Dishman, R. K. et al. Neurobiology of exercise. Obesity 14, 345-356 (2006).

28. Hoare, E., Stavreski, B., Jennings, G. \& Kingwell, B. Exploring Motivation and Barriers to Physical Activity among Active and Inactive Australian Adults. Sports 5, 47 (2017).

29. Costello, E., Kafchinski, M., Vrazel, J. \& Sullivan, P. Motivators, barriers, and beliefs regarding physical activity in an older adult population. J. Geriatr. Phys. Ther. 34, 138-147 (2011).

30. Gibala, M. J. et al. Short-term sprint interval versus traditional endurance training: Similar initial adaptations in human skeletal muscle and exercise performance. J. Physiol. 575, 901-911 (2006)

31. Little, J. P., Jung, M. E., Wright, A. E., Wright, W. \& Manders, R. J. F. Effects of high-intensity interval exercise versus continuous moderate-intensity exercise on postprandial glycemic control assessed by continuous glucose monitoring in obese adults. Appl. Physiol. Nutr. Metab. 39, 835-841 (2014).

32. Gillen, J. B. et al. Twelve Weeks of Sprint Interval Training Improves Indices of Cardiometabolic Health Similar to Traditional Endurance Training despite a Five-Fold Lower Exercise Volume and Time Commitment. PLoS One 11, e0154075 (2016).

33. Gillen, J. B. \& Gibala, M. J. Is high-intensity interval training a time-efficient exercise strategy to improve health and fitness? Appl. Physiol. Nutr. Metab. 39, 409-412 (2018).

34. Billat, L. V. Interval Training for Performance: A Scientific and Empirical Practice. Sport. Med. 31, 13-31 (2001).

35. Maclnnis, M. J. \& Gibala, M. J. Physiological adaptations to interval training and the role of exercise intensity. J. Physiol. 595, 2915-2930 (2017).

Page $10 / 16$ 
36. Buchheit, M. \& Laursen, P. B. High-intensity interval training, solutions to the programming puzzle: Part Il: Anaerobic energy, neuromuscular load and practical applications. Sports Medicine vol. 43 927-954 (2013).

37. Forti, L. N. et al. Dose-and gender-specific effects of resistance training on circulating levels of brain derived neurotrophic factor (BDNF) in communitydwelling older adults. Exp. Gerontol. 70, 144-149 (2015).

38. Chan, C. B. \& Ye, K. Sex Differences in Brain-Derived Neurotrophic Factor Signaling and Functions. J. Neurosci. Res. 95, 328-335 (2017).

39. Antunes, B. M., Rossi, F. E., Teixeira, A. M. \& Lira, F. S. Short-time high-intensity exercise increases peripheral BDNF in a physical fitness-dependent way in healthy men. Eur. J. Sport Sci. 20, 1-8 (2019).

40. Babaei, P., Damirchi, A., Mehdipoor, M. \& Tehrani, B. S. Long term habitual exercise is associated with lower resting level of serum BDNF. Neurosci. Lett. 566, 304-308 (2014)

41. Saucedo Marquez, C. M., Vanaudenaerde, B., Troosters, T. \& Wenderoth, N. High-intensity interval training evokes larger serum BDNF levels compared with intense continuous exercise. J. Appl. Physiol. 119, 1363-1373 (2015).

42. Jeon, Y. K. \& Ha, C. H. The effect of exercise intensity on brain derived neurotrophic factor and memory in adolescents. Environ. Health Prev. Med. 22, (2017).

43. Rodriguez, A. L. et al. Acute high-intensity interval exercise induces greater levels of serum brain-derived neurotrophic factor in obese individuals. Exp. Biol. Med. 243, 1153-1160 (2018).

44. Moher, D. et al. Preferred reporting items for systematic review and meta-analysis protocols (PRISMA-P) 2015 statement. Syst. Rev. 4, 148-160 (2015).

45. Lee, E. et al. An optimal search filter for retrieving systematic reviews and meta-analyses. BMC Medical Research Methodology vol. 12 1-11 (2012).

46. Smart, N. A. et al. Validation of a new tool for the assessment of study quality and reporting in exercise training studies. Int. J. Evid. Based. Healthc. 13, 9-18 (2015).

47. Borenstein, M., Hedges, L. V., Higgins, J. P. T. \& Rothstein, H. R. Introduction to Meta-Analysis. Introduction to Meta-Analysis (John Wiley \& Sons, Ltd, 2009). doi:10.1002/9780470743386.

48. Morris, S. B. Estimating Effect Sizes From Pretest-Posttest-Control Group Designs. Organ. Res. Methods 11, 364-386 (2008).

49. DerSimonian, R. \& Laird, N. Meta-analysis in clinical trials. Control. Clin. Trials 7, 177-188 (1986).

50. Cohen, J. A power primer. Psychol. Bull. 112, 155-159 (1992).

51. Furuya-Kanamori, L., Barendregt, J. J. \& Doi, S. A. R. A new improved graphical and quantitative method for detecting bias in meta-analysis. Int. J. Evid. Based. Healthc. 16, 195-203 (2018).

52. Sterne, J. A. C. et al. Recommendations for examining and interpreting funnel plot asymmetry in meta-analyses of randomised controlled trials. BMJ $\mathbf{3 4 3}$, (2011).

53. Cochran, W. G. The Combination of Estimates from Different Experiments. Biometrics 10, 101 (1954).

54. Higgins, J. P. T., Thompson, S. G., Deeks, J. J. \& Altman, D. G. Measuring inconsistency in meta-analyses. British Medical Journa/vol. $327557-560$ (2003).

55. Furuya-Kanamori, L., Doi, S. A., Furuya-Kanamori, L. \& Doi, S. A. LFK: Stata module to compute LFK index and Doi plot for detection of publication bias in meta-analysis. (2020).

56. Slusher, A. L., Patterson, V. T., Schwartz, C. S. \& Acevedo, E. O. Impact of high intensity interval exercise on executive function and brain derived neurotrophic factor in healthy college aged males. Physiol. Behav. 191, 116-122 (2018).

57. Reycraft, J. T. et al. Exercise Intensity and Recovery on Circulating Brain-derived Neurotrophic Factor. Medicine and Science in Sports and Exercise vol. 52 (2019).

58. Dinoff, A., Herrmann, N., Swardfager, W. \& Lanctôt, K. L. The effect of acute exercise on blood concentrations of brain-derived neurotrophic factor in healthy adults: a meta-analysis. Eur. J. Neurosci. 46, 1635-1646 (2017).

59. Burgomaster, K. A. et al. Similar metabolic adaptations during exercise after low volume sprint interval and traditional endurance training in humans. J. Physiol. 586, 151-160 (2008).

60. Cabral-Santos, C. et al. Inflammatory Cytokines and BDNF Response to High-Intensity Intermittent Exercise: Effect the Exercise Volume. Front. Physiol. 7, 1-8 (2016).

61. El Hayek, L. et al. Lactate mediates the effects of exercise on learning and memory through sirt1-dependent activation of hippocampal brain-derived neurotrophic factor (BDNF). J. Neurosci. 39, 2369-2382 (2019).

62. Yang, J. et al. Lactate promotes plasticity gene expression by potentiating NMDA signaling in neurons. Proc. Natl. Acad. Sci. 111, 12228-12233 (2014).

63. Schiffer, T. et al. Lactate infusion at rest increases BDNF blood concentration in humans. Neurosci. Lett. 488, 234-237 (2011).

64. Brooks, G. A. The Science and Translation of Lactate Shuttle Theory. Cell Metab. 27, 757-785 (2018).

65. Hashimoto, T. et al. Maintained exercise-enhanced brain executive function related to cerebral lactate metabolism in men. FASEB J. 32, 1417-1427 (2018).

66. Domínguez-sanchéz, M. A., Bustos-cruz, R. H. \& Velasco-orjuela, G. P. Acute Effects of High Intensity, Resistance, or Combined Protocol on the Increase of Level of Neurotrophic Factors in Physically Inactive Overweight Adults : The BrainFit Study. Front. Physiol. 9, 1-12 (2018).

67. Radka, S. F., Holst, P. A., Fritsche, M. \& Altar, C. A. Presence of brain-derived neurotrophic factor in brain and human and rat but not mouse serum detected by a sensitive and specific immunoassay. Brain Res. 709, 122-130 (1996). 
68. Fujimura, H. et al. Brain-derived neurotrophic factor is stored in human platelets and released by agonist stimulation. Thromb. Haemost. 87, 728-734 (2002).

69. Karege, F. et al. Low Brain-Derived Neurotrophic Factor (BDNF) levels in serum of depressed patients probably results from lowered platelet BDNF release unrelated to platelet reactivity. Biol. Psychiatry 57, 1068-1072 (2005).

70. Polyakova, M. et al. Stability of bdnf in human samples stored up to 6 months and correlations of serum and edta-plasma concentrations. Int. J. Mol. Sci. 18, 1-11 (2017).

71. Maffioletti, E., Zanardini, R., Gennarelli, M. \& Bocchio-Chiavetto, L. Influence of clotting duration on brain-derived neurotrophic factor (BDNF) dosage in serum. Biotechniques 57, 111-114 (2014).

72. Cho, H. C. et al. The concentrations of serum, plasma and platelet BDNF are all increased by treadmill VO 2 max performance in healthy college men. Neurosci. Lett. 519, 78-83 (2012).

73. Cipryan, L. The effect of fitness level on cardiac autonomic regulation, IL-6, total antioxidant capacity, and muscle damage responses to a single bout of high-intensity interval training. J. Sport Heal. Sci. 7, 363-371 (2016).

74. Tao Yu, Yun Chang, Xiao Lin Gao, Han Li, P. Z. et al. Dynamic Expression and the Role of BDNF in Exercise-induced Skeletal Muscle Regeneration. Physiol. Biochem. 38, 959-966 (2017).

75. Correia, P. R. et al. Increased basal plasma brain-derived neurotrophic factor levels in sprint runners. Neurosci. Bull. 27, 325-329 (2011).

76. Nofuji, Y. et al. Different Circulating BDNF Responses to Acute Exercise Between Physically Active and Sedentary Subjects. J. Sports Sci. Med. 11, 83-88 (2012).

77. Saanijoki, T. et al. Affective Adaptation to Repeated SIT and MICT Protocols in Insulin-Resistant Subjects. Med. Sci. Sports Exerc. 50, 18-27 (2018).

78. Heisz, J. J., Tejada, M. G. M., Paolucci, E. M. \& Muir, C. Enjoyment for high-intensity interval exercise increases during the first six weeks of training: Implications for promoting exercise adherence in sedentary adults. PLoS One 11, 1-10 (2016).

79. García-Pinillos, F., Soto-Hermoso, V. M. \& Latorre-Román, P. A. How does high-intensity intermittent training affect recreational endurance runners? Acute and chronic adaptations: A systematic review. J. Sport Heal. Sci. 6, 54-67 (2017).

80. Monje, C. et al. Effects of a high intensity interval session on mucosal immune function and salivary hormones in male and female endurance athletes. J. Sport. Sci. Med. 19, 436-443 (2020).

81. Tanner, A. V., Nielsen, B. V. \& Allgrove, J. Salivary and plasma cortisol and testosterone responses to interval and tempo runs and a bodyweight-only circuit session in endurance-trained men. J. Sports Sci. 32, 680-689 (2014).

82. Issa, G., Wilson, C., Terry, A. V. B. \& Pillai, A. An inverse relationship between cortisol and BDNF levels in schizophrenia: Data from human postmortem and animal studies. Neurobiol. Dis. 39, 327-333 (2010).

83. Luine, V. \& Frankfurt, M. Interactions between estradiol, BDNF and dendritic spines in promoting memory. Neuroscience 239, 34-45 (2013).

84. Scharfman, H. E. \& MacLusky, N. J. Estrogen and brain-derived neurotrophic factor (BDNF) in hippocampus: Complexity of steroid hormone-growth factor interactions in the adult CNS. Front. Neuroendocrinol. 27, 415-435 (2006).

85. Langhnoja, J. M., Buch, L. K. \& Pillai, P. P. 17ß-estradiol modulates NGF and BDNF expression through ER $\beta$ mediated ERK signaling in cortical astrocytes. Biologia (Bratisl). 73, 907-915 (2018).

86. Kight, K. E. \& McCarthy, M. M. Sex differences and estrogen regulation of BDNF gene expression, but not propeptide content, in the developing hippocampus. J. Neurosci. Res. 95, 345-354 (2017).

87. Wu, Y. W. C., Du, X., Van Den Buuse, M. \& Hill, R. A. Analyzing the influence of BDNF heterozygosity on spatial memory response to $17 \beta$-estradiol. Transl. Psychiatry 5, e498-e498 (2015).

88. Farage, M. A., Neill, S. \& MacLean, A. B. Physiological changes associated with the menstrual cycle a review. Obstet. Gynecol. Surv. 64, 58-72 (2009).

89. Draper, C. F. et al. Menstrual cycle rhythmicity: metabolic patterns in healthy women. Sci. Rep. 8, 1-15 (2018).

90. Szuhany, K. L., Bugatti, M. \& Otto, M. W. A meta-analytic review of the effects of exercise on brain-derived neurotrophic factor. J. Psychiatr. Res. 60, 56-64 (2015).

91. Liu, J. xin, Zhu, L., Li, P. jun, Li, N. \& Xu, Y. bing. Effectiveness of high-intensity interval training on glycemic control and cardiorespiratory fitness in patients with type 2 diabetes: a systematic review and meta-analysis. Aging Clin. Exp. Res. 31, 575-593 (2019).

92. Milanović, Z., Sporiš, G. \& Weston, M. Effectiveness of High-Intensity Interval Training (HIT) and Continuous Endurance Training for VO2max Improvements: A Systematic Review and Meta-Analysis of Controlled Trials. Sport. Med. 45, 1469-1481 (2015).

93. Sultana, R. N., Sabag, A., Keating, S. E. \& Johnson, N. A. The Effect of Low-Volume High-Intensity Interval Training on Body Composition and Cardiorespiratory Fitness: A Systematic Review and Meta-Analysis. Sports Medicine vol. 49 1687-1721 (2019).

94. Caldas-Costa, E. et al. Effects of High-Intensity Interval Training Versus Moderate-Intensity Continuous Training On Blood Pressure in Adults with Pre- to Established Hypertension: A Systematic Review and Meta-Analysis of Randomized Trials. Sport. Med. 48, 2127-2142 (2018).

\section{Figures}




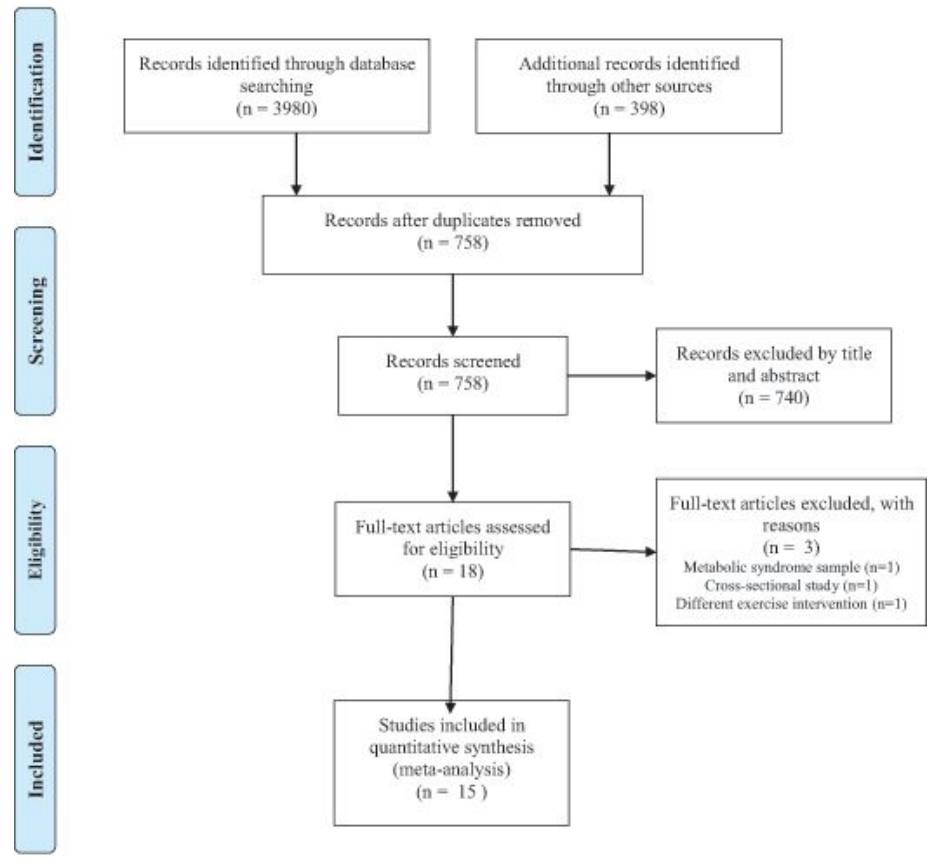

\section{Figure 1}

Flow diagram depicting the search process.

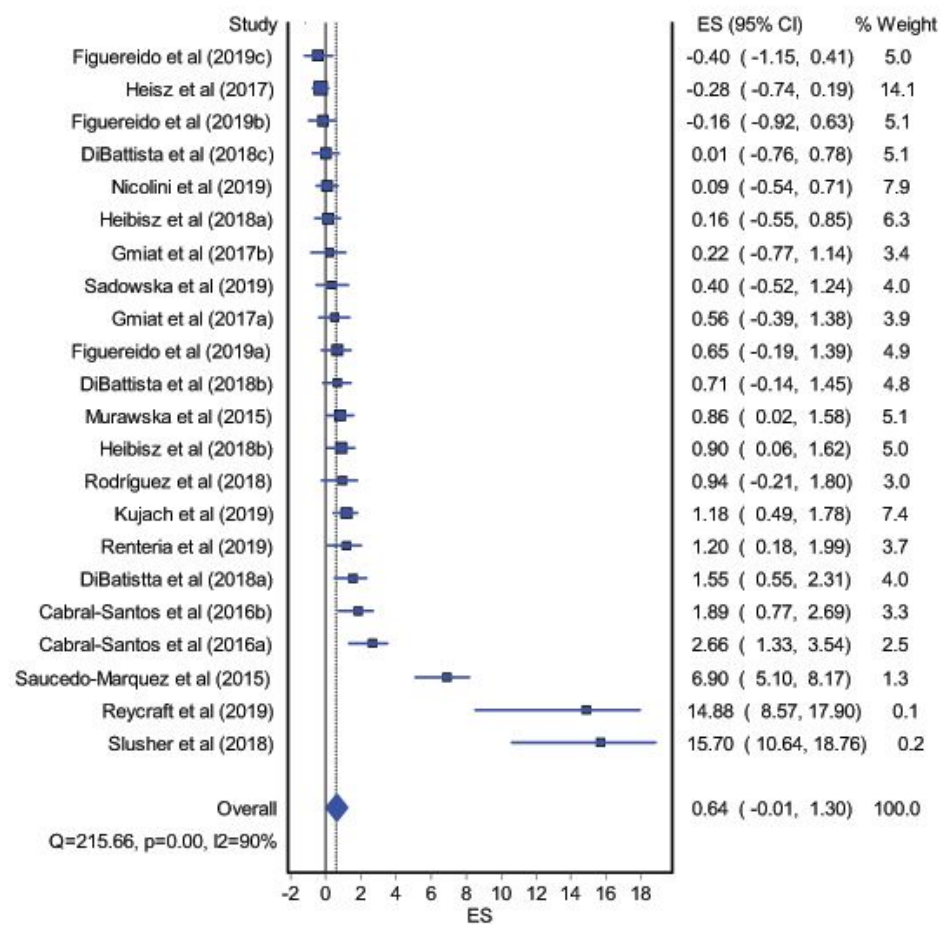

\section{Figure 2}

The overall effect of interval training (IT) on peripheral BDNF concentration. The lines indicate $95 \%$ confidence intervals (CI), and the square reflects the standardized differences (SMD) for each study. The diamond in the forest plot indicates the overall effect size (ES). 


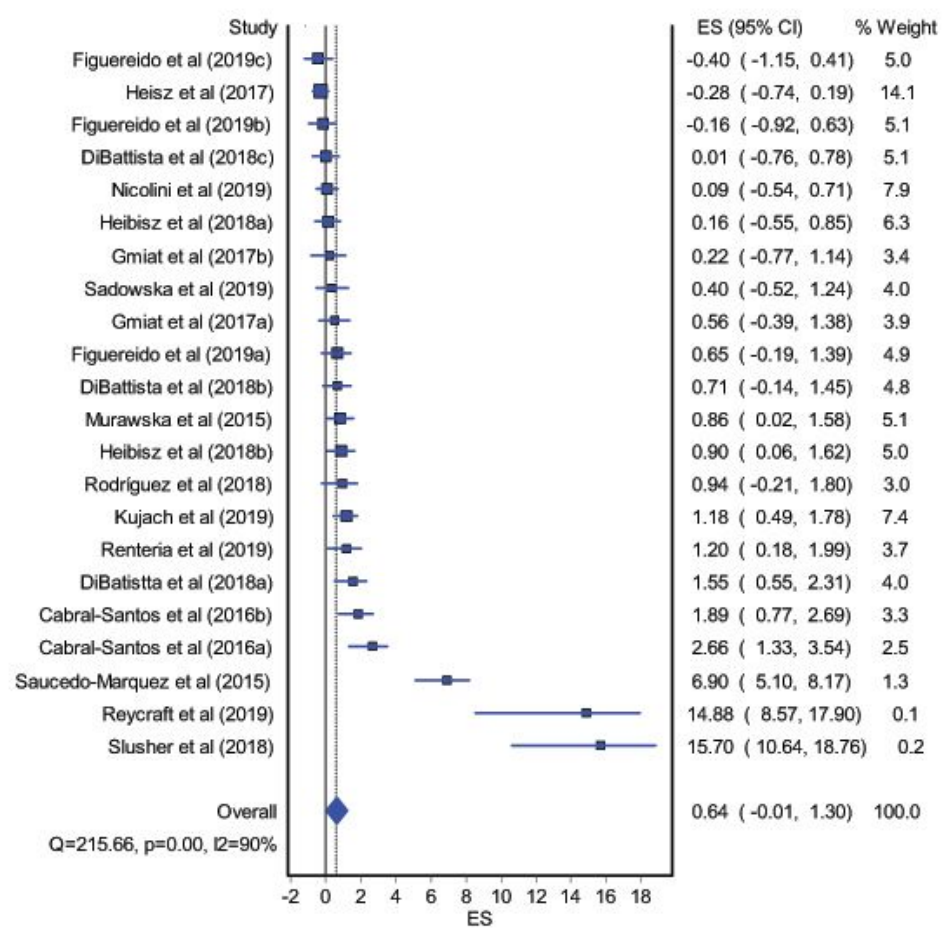

Figure 2

The overall effect of interval training (IT) on peripheral BDNF concentration. The lines indicate $95 \%$ confidence intervals (CI), and the square reflects the standardized differences (SMD) for each study. The diamond in the forest plot indicates the overall effect size (ES).

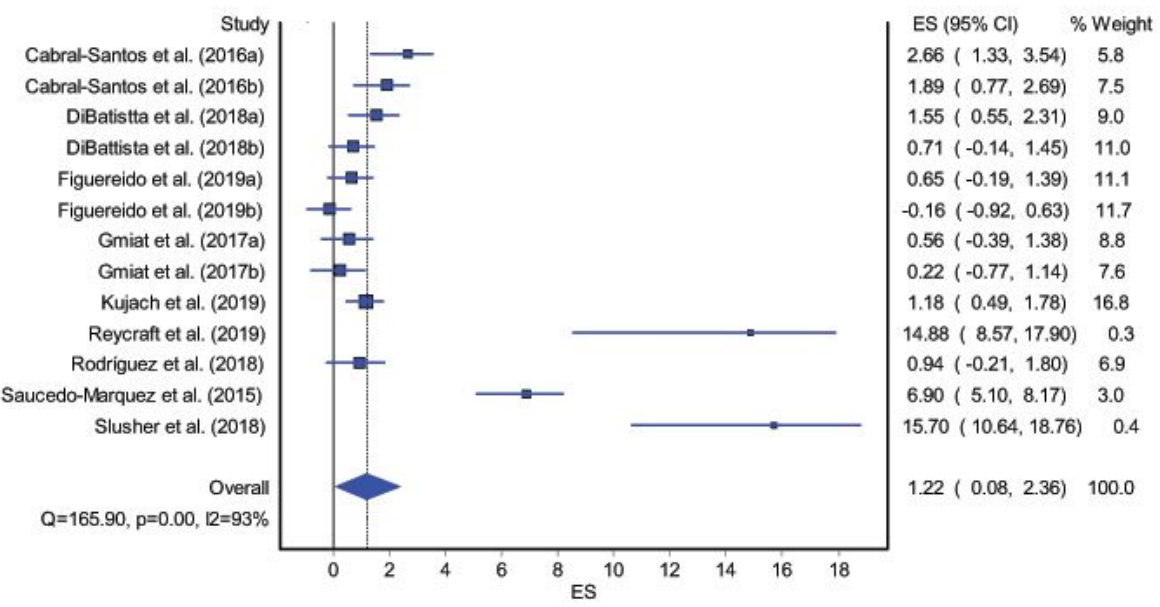

Figure 3

The effect of acute interval training (IT) on circulating BDNF concentration. The lines indicate $95 \%$ confidence intervals (CI), and the square reflect the standardized differences (SMD) for each study. The diamond in the forest plot indicates the overall effect size (ES). 


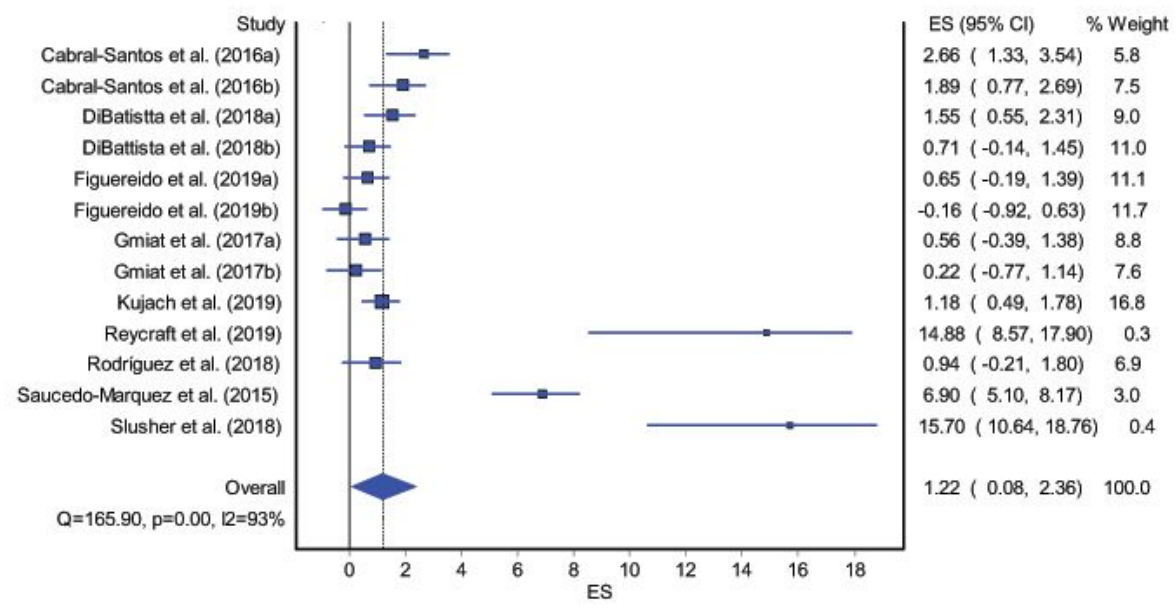

Figure 3

The effect of acute interval training (IT) on circulating BDNF concentration. The lines indicate $95 \%$ confidence intervals (Cl), and the square reflect the standardized differences (SMD) for each study. The diamond in the forest plot indicates the overall effect size (ES).

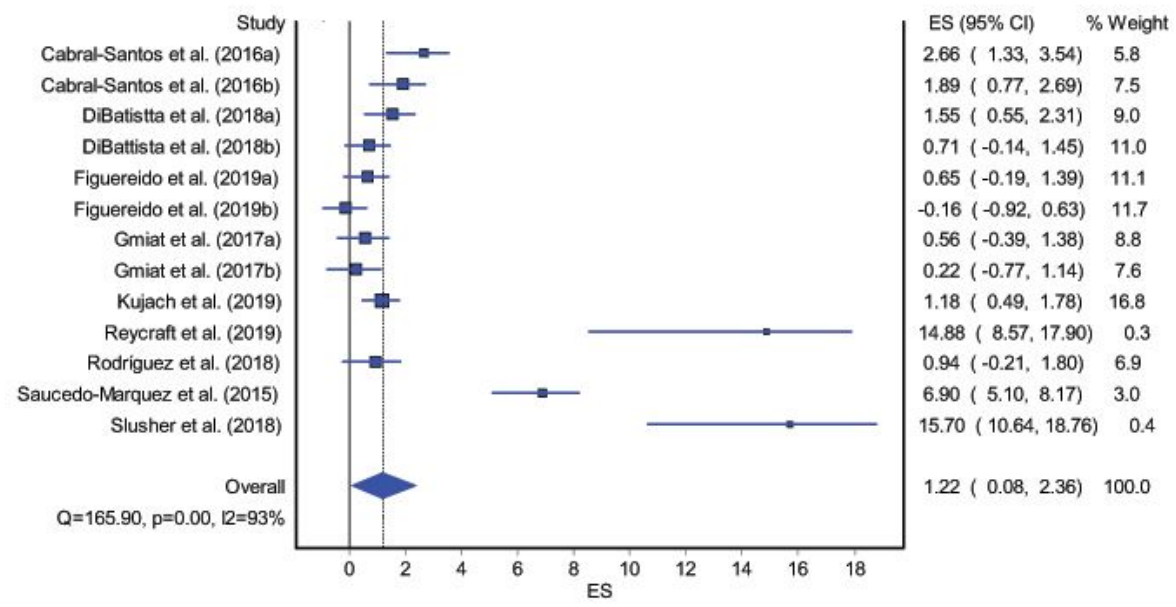

Figure 3

The effect of acute interval training (IT) on circulating BDNF concentration. The lines indicate $95 \%$ confidence intervals (CI), and the square reflect the standardized differences (SMD) for each study. The diamond in the forest plot indicates the overall effect size (ES).

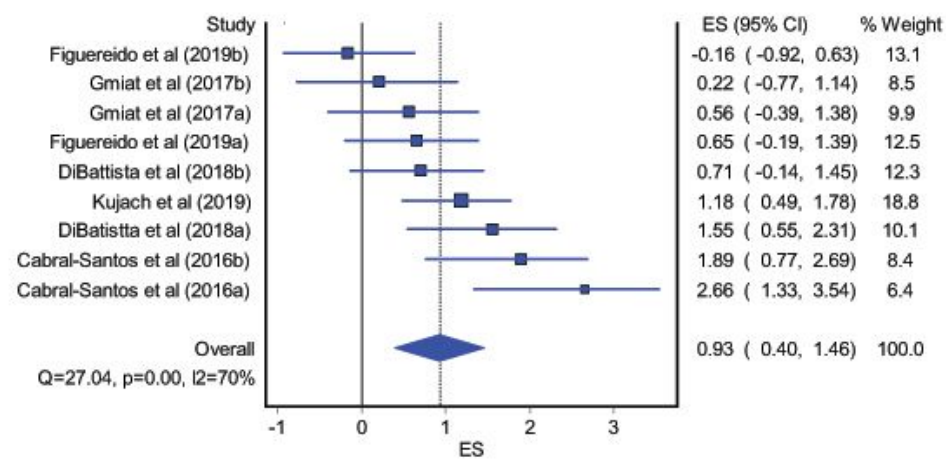

\section{Figure 4}

The effect of chronic interval training (IT) on circulating BDNF concentration. The lines indicate $95 \%$ confidence intervals (CI), and the square reflects the standardized differences (SMD) for each study. The diamond in the forest plot indicates the overall effect size (ES). 


\section{Supplementary Files}

This is a list of supplementary files associated with this preprint. Click to download.

- LegendsSupplementaryfigures.doc

- supplemetaryfigure1.tiff

- supplemetaryfigure1.tiff

- supplementaryfigure2.eps

- supplementaryfigure2.eps

- supplementaryfigure3.eps

- supplementaryfigure3.eps

- supplementaryfigure4.eps

- supplementaryfigure4.eps

- supplementaryfigure4.eps 